\title{
Implant assisted obturator in patient after maxillectomy: a case report
}

\author{
Yoon-Hee Seo, Joon-Seok Lee, Young-Gyun Song* \\ Department of Prosthodontics, College of Dentistry, Dankook University, Cheonan, Republic of Korea
}

Reconstruction of the maxillectomy with an obturator is to restore masticatory, swallowing, phonetic and esthetic problems. Stress created by lateral forces is minimized by the proper selection of an occlusal scheme, elimination of premature occlusal contacts, and wide distribution of supporting area. It should be considered that properly designed retainers reduce the stresses transmitted to the abutment while the obturator is in function. The following clinical report presents palatal obturator treatment with implant assisted removable partial denture (IARPD) design that restores normal function and esthetics in patients who experienced maxillectomy and dental implant failure. (J Dent Rehabil Appl Sci 2016;32(4):322-9)

Key words: maxillectomy; palatal obturator; implant assisted removable partial denture

\begin{abstract}
서론
선천적 구개열 또는 후천적으로 시행한 상악골 절제술 로 인해 구개 결손을 갖는 환자는 구강과 상악동 및 비강 의 개통으로 저작기능과 발음 및 심미적 문제를 가지며 일상생활에 많은 어려움을 가진다. 구개 결손 환자의 구 강 기능 회복과 일상생활이 가능하도록 하기 위해 결손 된 구개 부분을 폐쇄시키는 보철물인 구개폐쇄장치의 제 작이 필요하다.

구개폐쇄장치 디자인 시 통상적인 가철성 의치의 디 자인 원칙이 적용되나 상악골 결손부에서 지지를 얻을 수 없기 때문에 하중의 적절한 분배를 고려한 정확한 장 치 디자인과 잔존 조직 활용의 중요성이 강조된다. ${ }^{1-3}$ Aramany는 구개폐쇄장치를 디자인 하기에 앞서 적절한 결손부 분류가 필요함을 주장하며 상악절제술에 따른 결 손부를 형태에 따라 6가지로 분류하였으며 피개의치 또 는 클라스프를 사용한 의치 형태로 수복할 것을 제시하

*Correspondence to: Young-Gyun Song

Assistant Professor, Department of Prosthodontics, College of Dentistry, Dankook University, 119, Dandae-ro, Dongnam-gu, Cheonan, 31116, Republic of Korea Tel: +82-41-550,1932, Fax: +82-41-550-0116, E-mail: ygsong@dankook.ac.kr Received: September 8, 2016/Last Revision: September 10, 2016/Accepted: September 13, 2016
\end{abstract}

였다. ${ }^{1}$ 상악 결손부의 크기와 유형에 따라 달라질 수 있 으나 크게 수직 탈락력, 수직 교합력, torque 또는 회전 력, 측방력 및 전후방으로 가해지는 힘이 구개폐쇄장치 에 가해질 수 있다. 이 중에서 측방력으로 인해 야기되는 응력은 적절한 교합양식의 선택, 조기 교합접촉의 제거, 광범위한 지지영역의 활용으로 최소화 될 수 있다. 회전 력과 측방력에 의한 응력이 지대치로 전달되는 것을 줄 여주는 유지장치의 고안도 중요하다. ${ }^{2,3}$

본 증례보고에서는 임플란트와 milled bar attachment 를 이용한 구개폐쇄장치를 1 년 가량 사용한 후 임플란 트 실패를 경험한 환자에게 잔존 임플란트의 surveyed bridge와 클라스프 유지 가철성 국소의치 형태의 구개폐 쇄장치를 제작하여 추가적인 수술 없이 저작, 발음과 연 하기능 회복, 심미성 회복의 목적을 이루고 회전력과 측 방력이 가해질 때 임플란트 고정체에 전달되는 응력을 최소한으로 하는 안정적인 보철 수복을 하였음을 보고하 고자 한다.

Copyright C 2016 The Korean Academy of Stomatognathic Function and Occlusion. (c) It is identical to Creative Commons Non-Commercial License. 


\section{증례 보고}

60세 남자 환자로 좌측 상악동의 편평상피세포암종의 제거를 위하여 상악골 절제술을 받은 병력이 있는 환자 가 ‘오른쪽 임플란트가 아파서'라는 주소로 내원하였다. 상악에 잔존 자연치는 없었으며 1년 전 상악 우측 중절 치, 상악 우측 견치, 상악 우측 제1소구치, 상악 우측 제2 소구치, 상악 우측 제 1 대구치, 상악 우측 제 2 대구치 부위 에 임플란트를 식립하여 milled bar 장착과 구개폐쇄장
치를 제작하여 사용 중이었다(Fig. 1). 검사 결과 상악 우 측 대구치부의 임플란트의 심한 임플란트 주위염과 동요 도, 고정체 하방까지 이어진 골 소실이 관찰되어 해당 임 플란트의 제거가 필요한 상태였다(Fig. 2, 3). 상악 우측 대구치부를 제외한 나머지 임플란트는 동요도가 없고 임 플란트 주위염이 없거나 경미한 정도였다. 견고한 milled bar 유지장치가 과도한 후방연장을 갖는 상악골 결손부 수복에 사용되어 측방력과 회전력으로 인한 응력을 그 대로 임플란트에 전달하여 임플란트 실패가 일어난 것

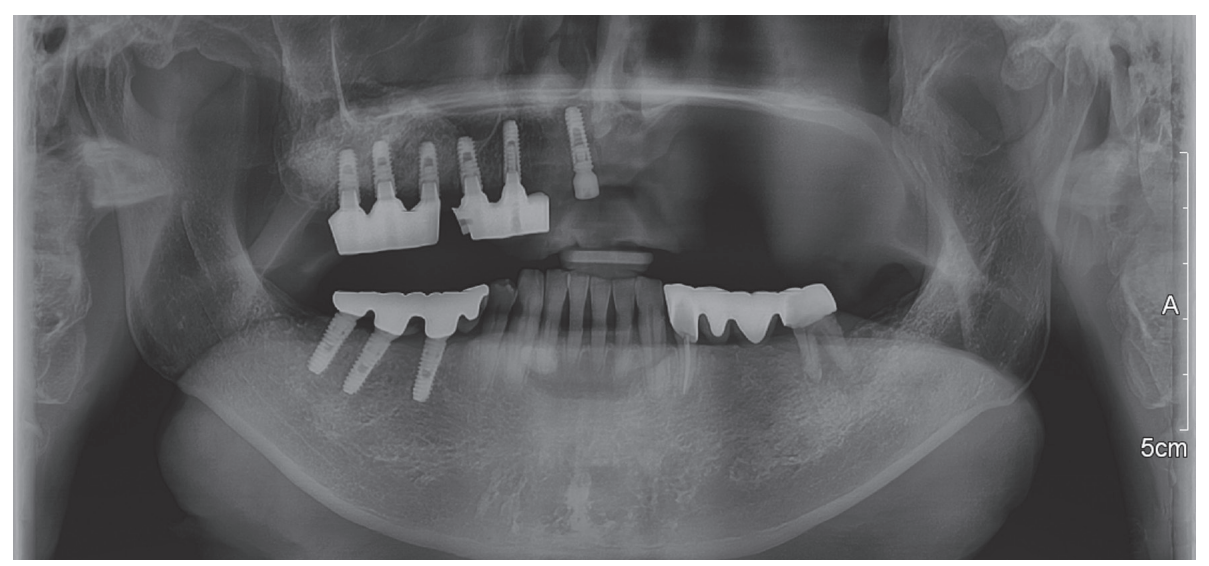

Fig. 1. Panoramic view of first visit.
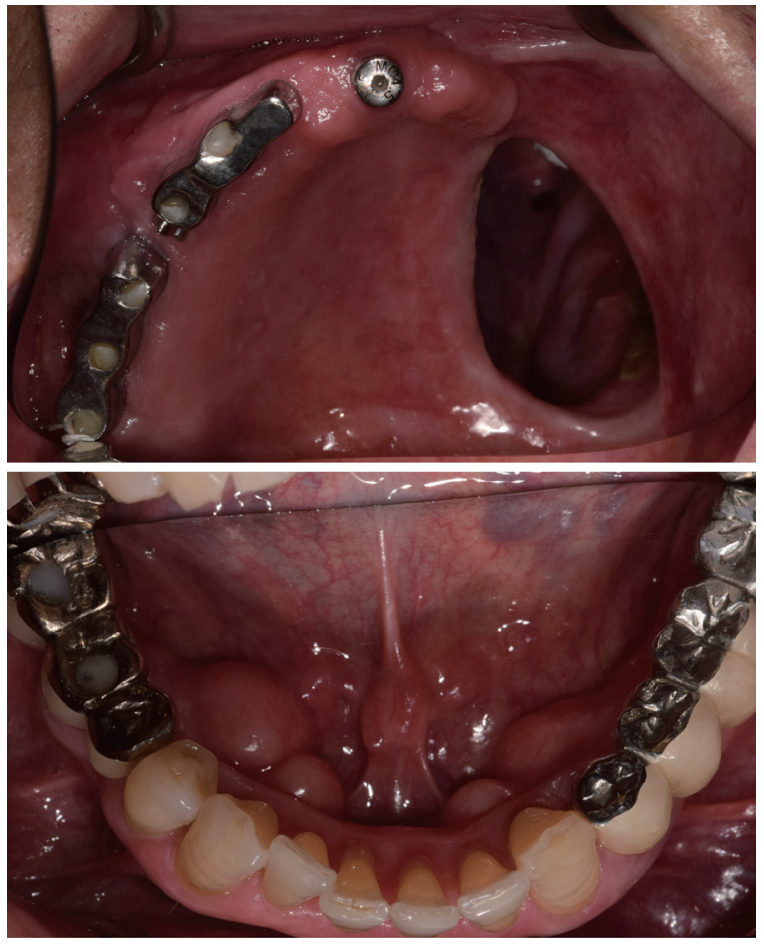

Fig. 2. Intraoral view of first visit.

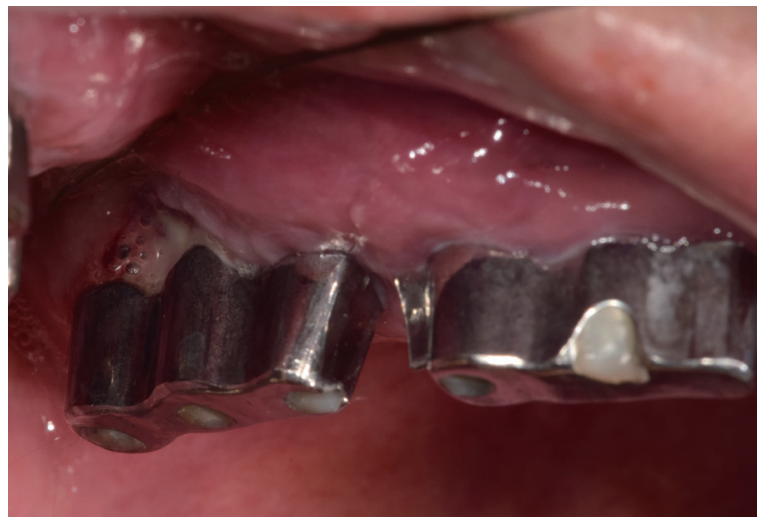

Fig. 3. Failed implant of maxillary right molars. 
으로 보였다. 환자는 추가적인 수술을 원하지 않았으며 실패된 임플란트 부위의 골량도 충분하지 않아서 잔존 된 상악 우측 소구치부와 상악 우측 전치부 임플란트에 surveyed bridge를 장착하고 클라스프 유지 가철성 국소 의치 유형의 폐쇄장치를 제작하는 보철수복계획을 세웠 다.

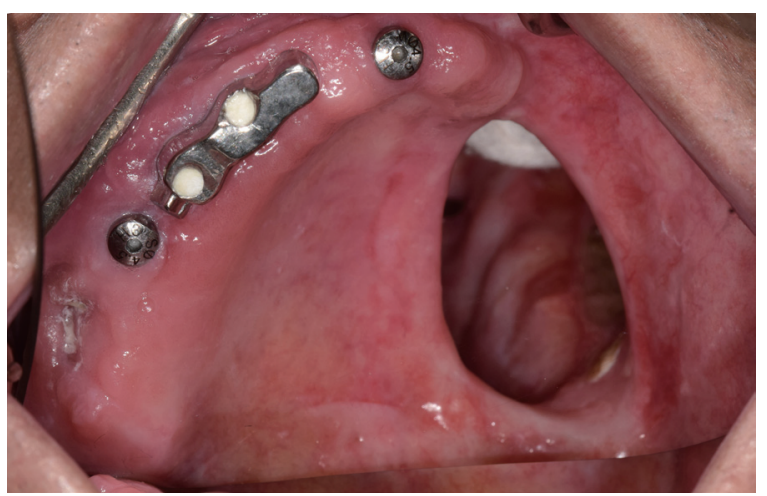

Fig. 4. Two weeks after removal of failed implant of maxillary right molars.

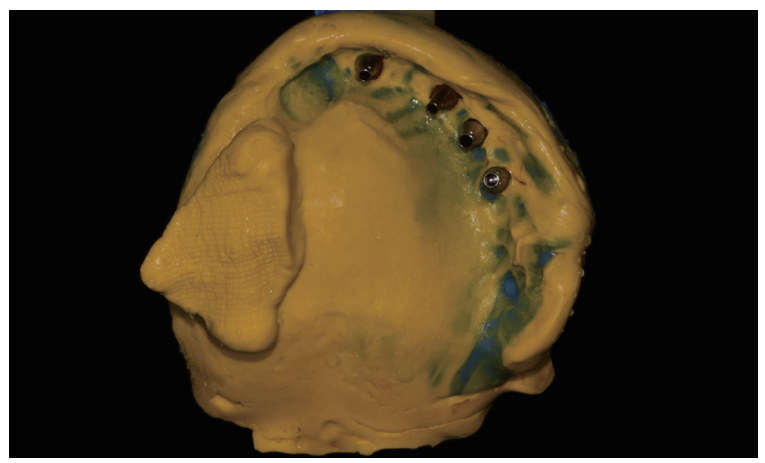

Fig. 5. Implant fixture level impression taking.

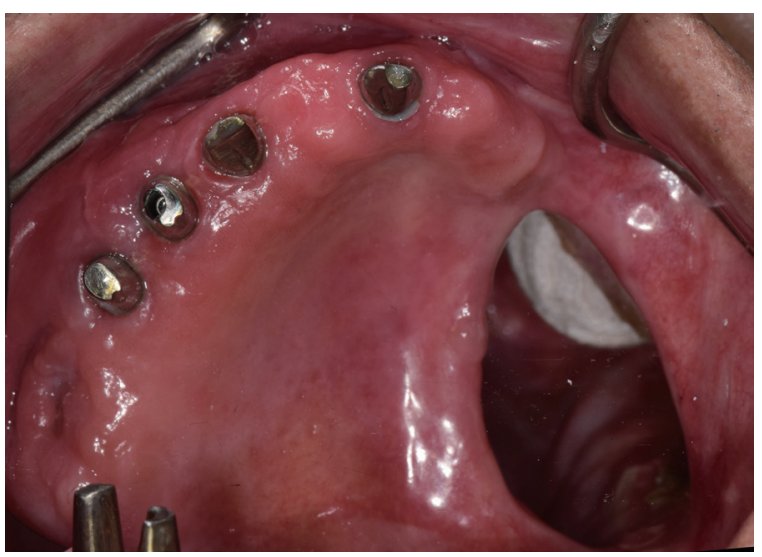

Fig. 6. Implant abutment try-in.
상악 우측 대구치부의 실패한 임플란트를 제거하였다 (Fig. 4). 상악 우측 소구치부와 상악 우측 전치부의 고 정체 수준에서 임플란트 인상을 채득하여 computeraided design and computer-aided manufacturing (CAD/ $\mathrm{CAM})$ 을 이용한 맞춤 지대주를 제작하였고 네 개의 임플 란트를 연결하는 surveyed bridge를 제작하여 장착하였 다(Fig. 5 - 7). 제작된 surveyed bridge의 상악 우측 중절 치 임플란트의 근심측 언더컷 하방은 공간을 주어 의치 의 측방 움직임이 있을 때 임플란트에 위해한 힘을 가하 지 않도록 설계하였다. 상악 우측 중절치 임플란트와 상 악 우측 견치 임플란트에 설면 레스트를 뚜렷하게 형성 해주었고, 상악 우측 제1소구치와 상악 우측 제2소구치 에 근심 레스트를 형성하였다(Fig. 7,8 ).

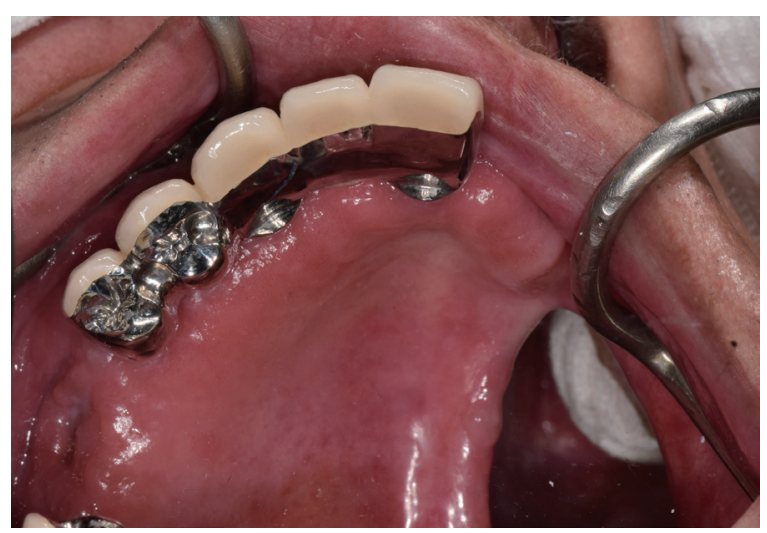

Fig. 7. Surveyed bridge fabrication.

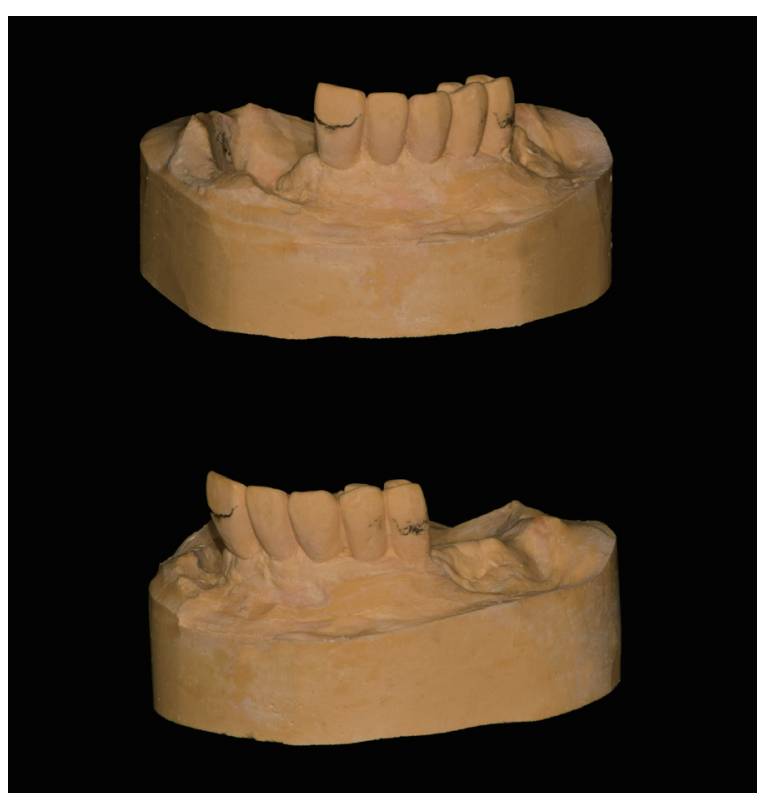

Fig. 8. Surveying. 
개인트레이를 제작하여 제작된 surveyed bridge를 위 치시킨 상태에서 실리콘 인상재를 이용하여 pick-up 인상 을 채득하였으며, 경석고를 사용하여 금속 구조물 제작 을 위한 모형을 제작하였다. 상악 우측 중절치의 임플란 트와 상악 우측 제 2 소구치의 임플란트 치관에 RPI 클라 스프를 형성하여 측방력의 직접적인 임플란트로의 전달 을 방지하여 금속 구조물을 제작하였으며, 구강 내에서 적합을 확인하고 기초상을 제작하였다. Coe-comfort ${ }^{\circledR}$ (GC America, Alsip, USA)를 이용하여 이차 인상을 채

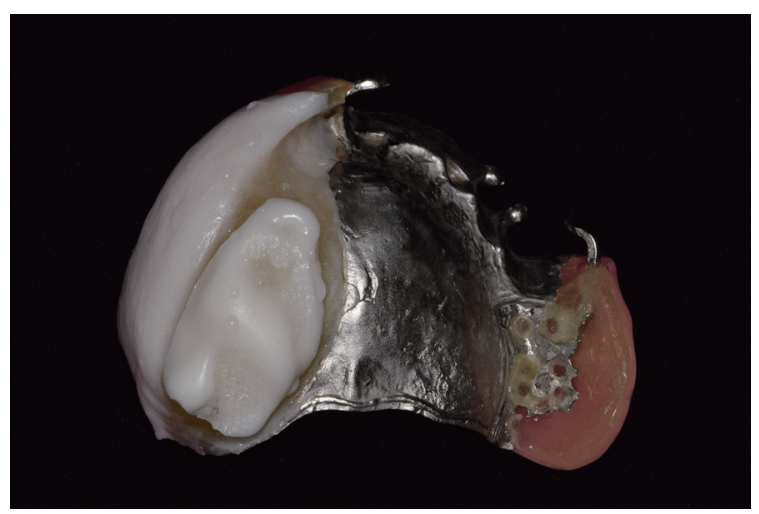

Fig. 9. Final impression with Coe-comfort ${ }^{\circledR}$ (GC America, Alsip, USA).
득하였고, 최종모형을 제작하였다(Fig. 9, 10). 안궁 이전 및 교합기에 mounting, 인공치 배열 후 납의치를 시적, 검사하였다(Fig. 11, 12). 의치상 레진을 온성하고 구강 내 교합 조정을 시행하여 구개폐쇄장치 제작을 완성하였 다(Fig. 13, 14). 환자는 1년 경과 관찰에서 저작과 발음, 심미에 만족하였으며, 검사 결과 임플란트 동요도나 조 직의 손상 또는 병변은 관찰되지 않았으며 구개폐쇄장치 와 surveyed bridge의 상태는 양호하였다.

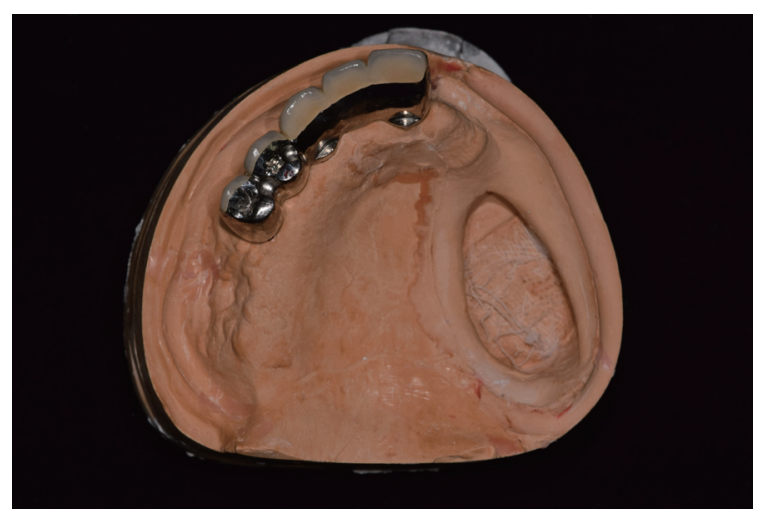

Fig. 10. Altered cast.

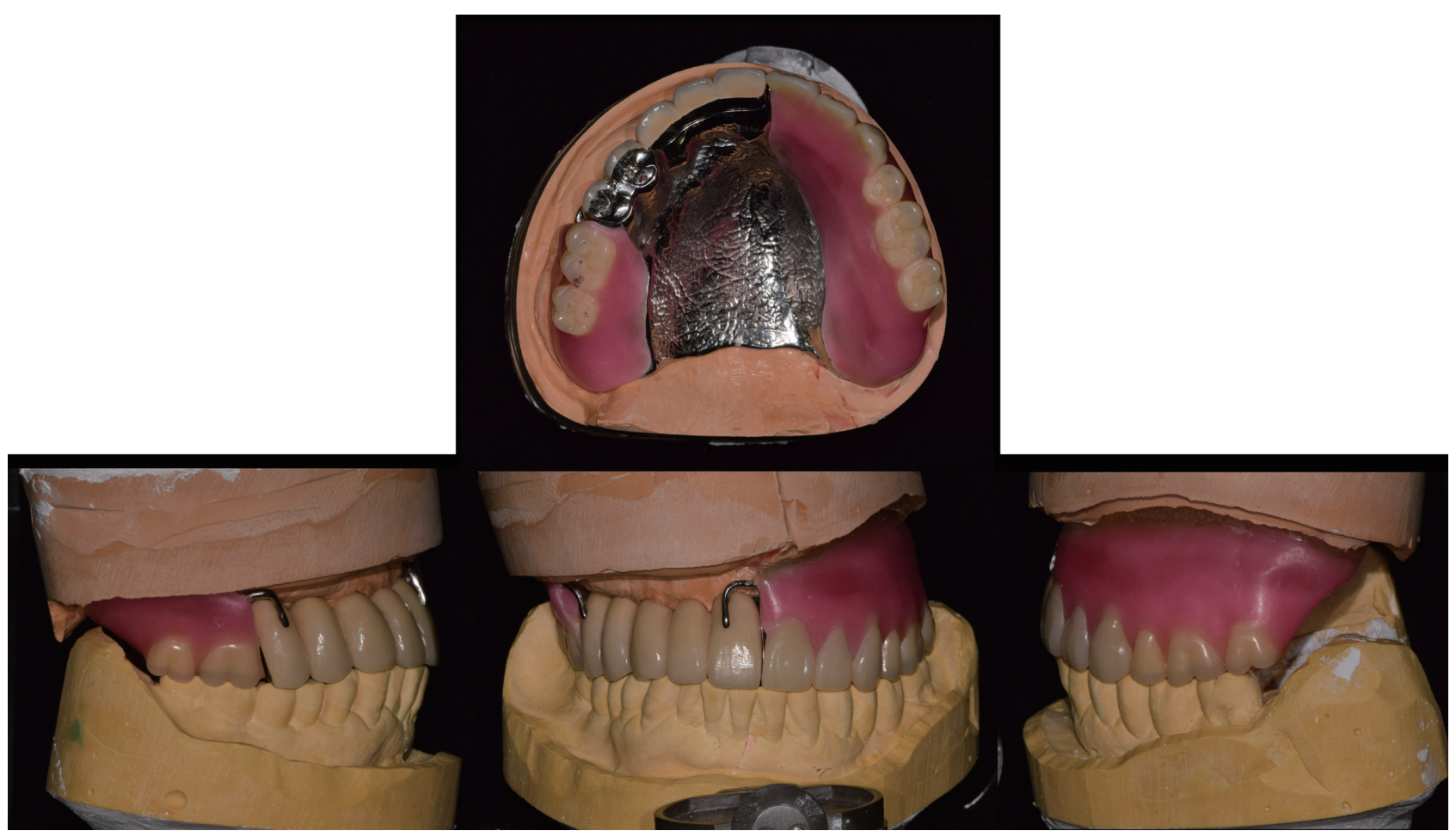

Fig. 11. Arrangement of artificial teeth. 


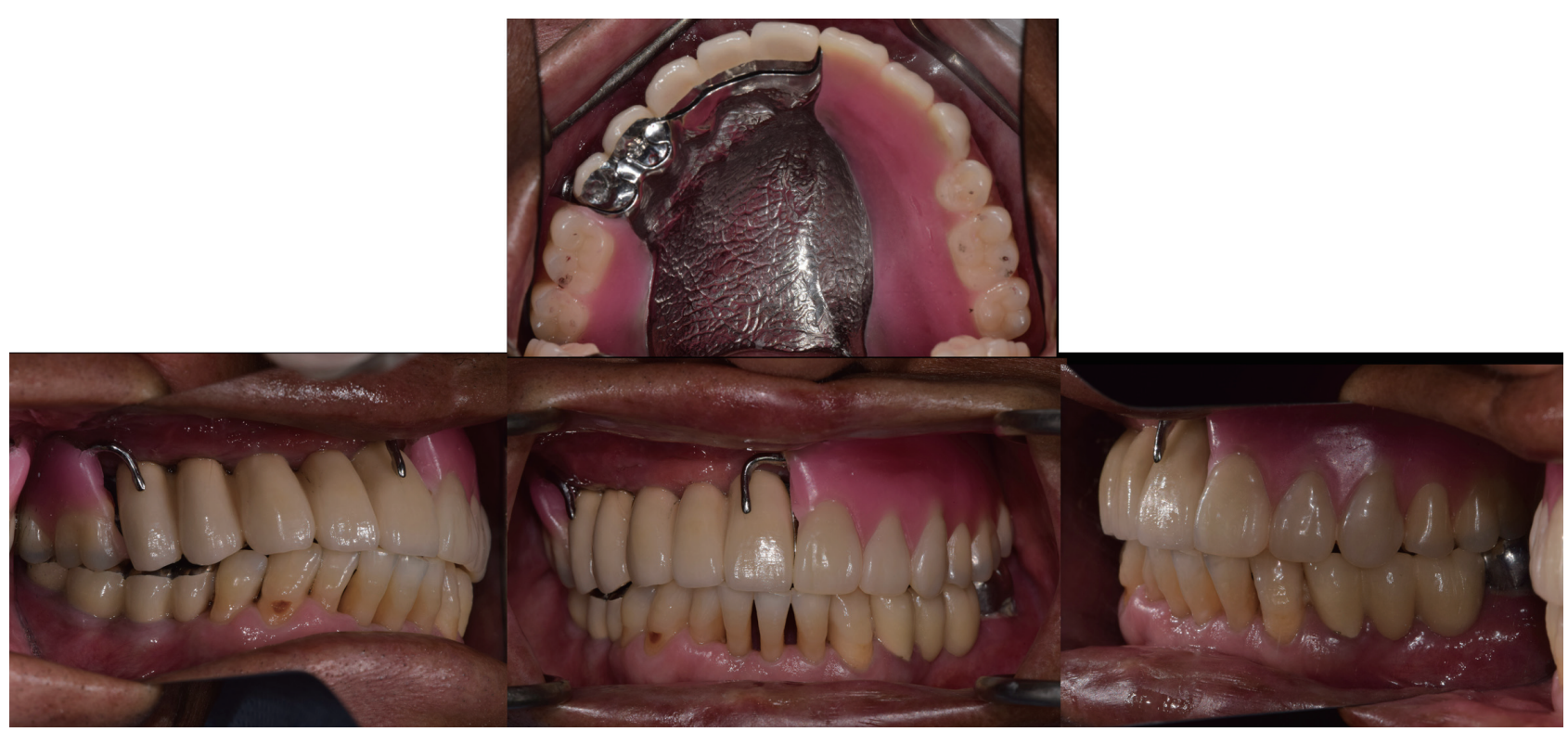

Fig. 12. Wax denture try-in.

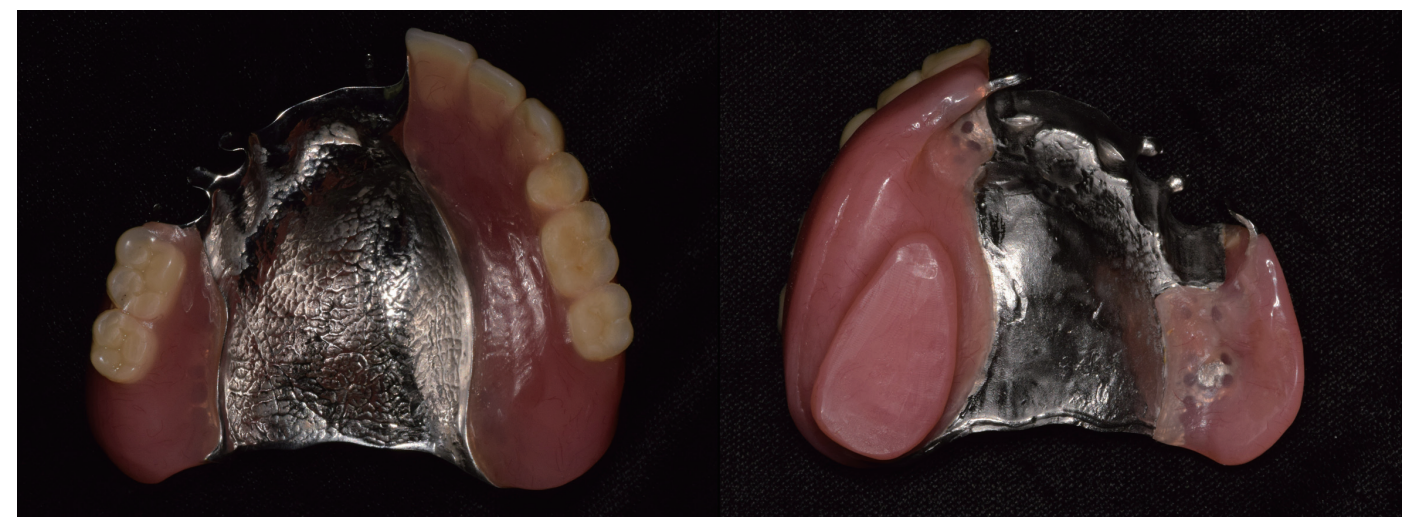

Fig. 13. Final prosthesis.

\section{고찰}

상악에 발생하는 악성종양의 치료를 위해서 시행되는 상악골 절제술은 구강, 비강, 상악동, 비인두를 개통시키 며 발음과 연하기능의 장애를 동반하므로 구개폐쇄장치 를 제작하여 기능회복을 위한 보철수복이 필수적이다. 구강 기능 회복을 위한 이러한 악안면 보철수복은 구개 폐쇄와 저작활동의 기능 및 심미적 요구를 모두 만족시 켜야 하는 복합치료이다. 구개폐쇄장치 디자인 시에 통 상적인 가철성 의치에서 고려사항뿐만 아니라 적절한 지 지를 얻기 위해 잔존치아, 치조제, 잔존 경구개를 적절히
활용해야 하며, 유지를 얻기 위해 잔존 연구개, 잔존 경 구개, 앞 콧구멍, 측방 반흔대, 측벽 높이를 활용할 수 있 다고 알려져 있다. ${ }^{1-3}$ 결손 부위의 크기와 위치에 따라 다 소간의 차이가 있지만 대부분의 경우 경구개 결손부에서 보철수복장치의 지지를 얻지 못하기 쉽고 이로 인해 저작 시 장치가 침하되어 반대쪽 장치 유지부에서 과도한 측 방력이 가해지기 쉽다. ${ }^{2,3}$

Milled bar attachment는 rigid한 attachment로 통상적 인 피개의치에서 사용되었을 경우 유지 지지 안정을 부여 하는 기능이 뛰어나 완전 무치악 환자에서 후방까지 충 분한 개수의 임플란트를 양측성으로 식립하는 것이 가능 


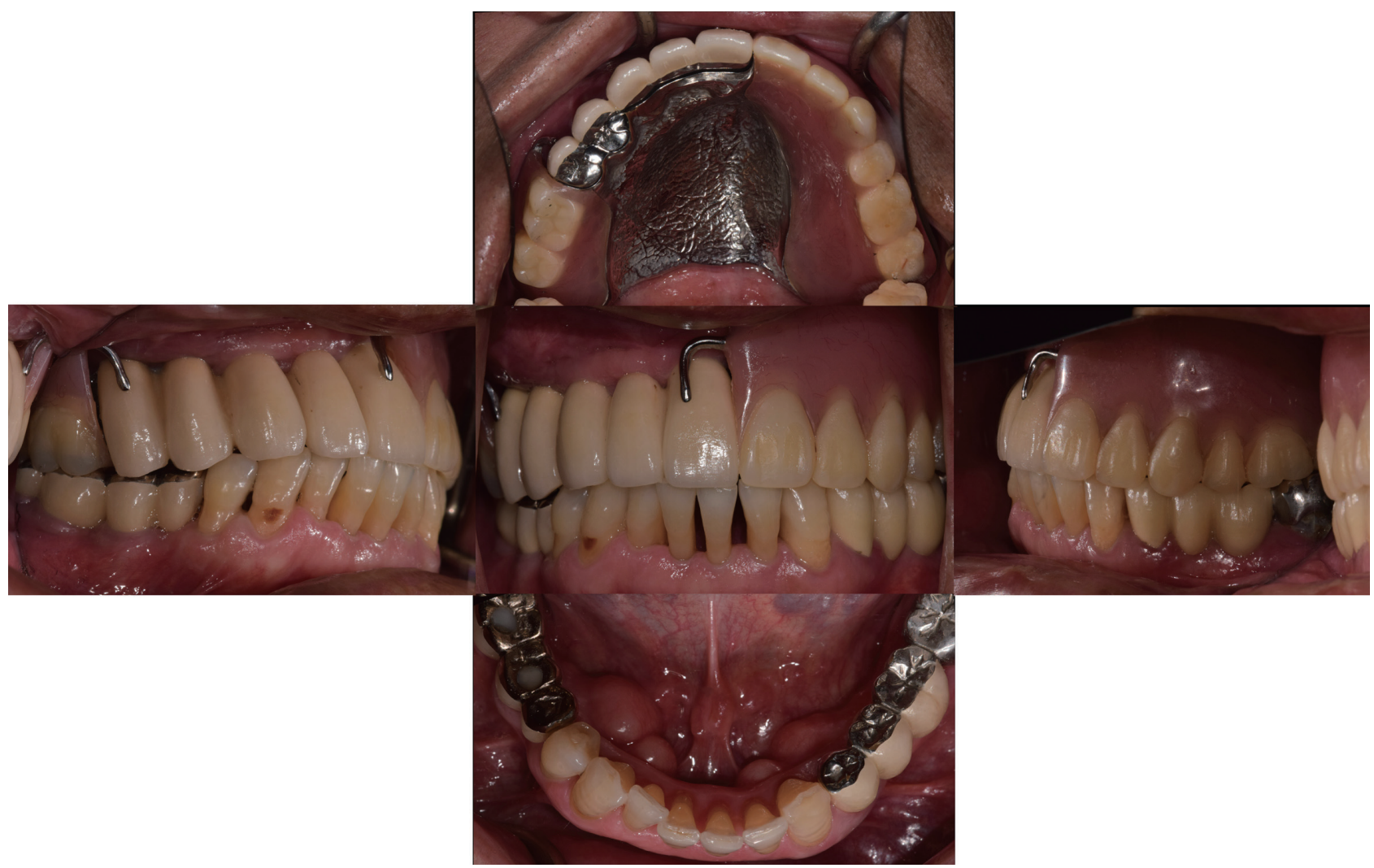

Fig. 14. Palatal obturator placement.

할 때에 사용된다. ${ }^{4}$ 상악골 절제술을 받은 환자에서 구개 결손부로 인한 의치의 침하와 tilting을 방지하고자 사용 되는 경우가 종종 있다. ${ }^{4-6}$ 그러나 계속해서 가해지는 측 방력을 그대로 임플란트 고정체로 전달하는 milled bar 의 사용은 임플란트의 실패를 초래할 수 있으므로 주의 해야 한다. 따라서 상악절제술 환자의 구개폐쇄장치에 서는 측방력을 고정체로 직접 전달하는 것을 최소화하 기 위하여 클라스프 디자인을 하거나 피개의치 형태로서 non-rigid attachment를 사용하는 것을 고려해야 할 것이 다. ${ }^{2,7}$

Jang 등은 하악 전치가 잔존한 환자에서 하악 견치부 위에 임플란트를 식립하여 surveyed crown을 장착하고 후방연장 가철성 국소의치를 제작하여 성공적인 예후 를 보인 것을 보고하였으며, ${ }^{8} \mathrm{Na}$ 등은 전치부 임플란트 에 surveyed bridge를 장착하고 후방연장 가철성 국소의 치를 사용하여 수복한 사례를 보고하였다. 또한 Kim등 은 상악 좌측 제 2 소구치와 상악 좌측 제 1,2 대구치의 임 플란트에 surveyed bridge를 제작하여 가철성 국소의치
의 지대치로 사용하여 5년 관찰에서 양호한 예후를 보 였음을 보고하였다. ${ }^{10}$ 임플란트에 surveyed crown 또는 bridge를 장착하여 가철성 국소의치의 지대치로 활용할 수 있는 경우는 1) 기존 식립된 임플란트를 가철성 국소 의치에 활용하는 경우, 2) 심미성을 위해 상악전치부의 임플란트 보철물을 지대치로 사용하는 경우, 3) 역학적 으로 유리한 분포를 위해 전략적 위치에 임플란트를 위 치시키는 경우가 있으며, 이 때 성공적인 임플란트 예후 를 위하여 임플란트 식립 부위는 양호한 골질을 가져야 하며, 식립되는 임플란트는 길이와 폭이 충분해야 하며, 균등한 교합접촉을 이루도록 정확한 교합조정이 시행되 어야 한다. ${ }^{10,11}$

본 증례에서는 실패한 임플란트와 상부 milled bar attachment를 제거하고 잔존 임플란트를 이용하여 surveyed bridge와 RPI 클라스프 유지 국소의치 형태의 구개폐쇄장치를 이용하여 상악골 절제술 환자의 보철수 복을 완료하였다. Surveyed bridge의 명확한 레스트 형성 과 I-bar 사용으로 수직력이 주로 가해지도록 하였으며, 
회전력과 측방력은 임플란트 고정체에 최소한으로 전달 되도록 proximal plate에서 회전을 허용하도록 보철수복 을 설계하였다. 1 년 경과 관찰에서 발음과 저작, 연하, 심 미성과 잔존 임플란트의 추가적인 실패 양상이 보이지 않는 다는 점에서 양호한 보철수복 결과를 보여 본 증례 를 보고하는 바이다.

\section{결론}

본 증례에서는 좌측 상악골 절제술 후 milled bar를 이 용한 구개폐쇄장치 치료를 받은 뒤 불편을 호소하는 환 자에서 실패한 임플란트와 milled bar를 제거하고 구개폐 쇄장치를 재제작하였다. 과도한 측방력과 회전력이 임플 란트 고정체에 가해지는 것을 막기 위해 RPI 클라스프를 갖는 국소의치 형태의 구개폐쇄장치를 제작하여 발음, 저 작, 연하 등 환자의 기능을 회복시켰고 잔존 임플란트의 실패를 야기하지 않는 적절한 보철수복을 완료하였다.

\section{ORCID}

Joon-Seok Lee http://orcid.org/0000-0003-2962-1380

Young-Gyun Song http://orcid.org/0000-0003-37899585

\section{References}

1. Aramany MA. Basic principles of obturator design for partially edentulous patients. Part I: classification. J Prosthet Dent 1978;40:554-7.

2. Aramany MA. Basic principles of obturator design for partially edentulous patients. Part II: design principles. J Prosthet Dent 1978;40:656-62.

3. Desjardins RP. Early rehabilitative management of the maxillectomy patients. J Prosthet Dent 1977;38: 311-8.

4. Bueno-Samper A, Hernández-Aliaga M, CalvoGuirado JL. The implant-supported milled bar overdenture: a literature review. Med Oral Patol Oral Cir Bucal 2010;15:e375-8.

5. Fukuda M, Takahashi T, Nagai H, Iino M. Implantsupported edentulous maxillary obturators with milled bar attachments after maxillectomy. J Oral Maxillofac Surg 2004;62:799-805.

6. Takahashi T, Fukuda M, Funaki K, Tanaka K. Magnet-retained facial prosthesis combined with an implant-supported edentulous maxillary obturator: a case report. Int J Oral Maxillofac Implants 2006; 21:805-7.

7. Kim MJ, Hong SO. Finite element analysis on stress distribution of maxillary implant-retained overdentures depending on the bar attachment design and palatal coverage. J Adv Prosthodont 2016;8:85-93.

8. Jang Y, Emtiaz S, Tarnow DP. Single implant-supported crown used as an abutment for a removable cast partial denture: a case report. Implant Dent 1998;7:199-204.

9. Na HJ, Kang DW, Son MK. Distal-extension removable partial denture with anterior implant prostheses: case report. J Dent Rehabil Appl Sci 2011: 27:437-47.

10. Kim JH, Lee JH. An implant-supported removable partial denture for a patient with post-inflammatory scar contracture caused by burn complications: a clinical report. J Adv Prosthodont 2012;4:57-9.

11. Bortolini S, Natali A, Franchi M, Coggiola A, Consolo U. Implant-retained removable partial dentures: an 8-year retrospective study. J Prosthodont 2011;20:168-72. 


\section{상악골 절제 환자에서 임플란트를 이용한 구개폐쇄장치 증례}

\section{서윤희, 이준석, 송영균 ${ }^{*}$}

단국대학교 치과대학 치과보철학교실

상악골 절제술을 받은 환자의 구개폐쇄장치 보철 수복은 구강과 비강 및 상악동의 개통으로 인한 저작기능, 연하, 발음 및 심미성의 상실을 회복하는 것을 목적으로 하는 치료이다. 상악골 절제술 환자에서 구개폐쇄장치 설계 시 측방력으로 인해 야기되는 응력은 적절한 교합 양식의 선택, 조기 교합접촉의 제거, 광범위한 지지영역의 활용으로 최소화될 수 있다. 또한 기능 시 응력이 지대치로 전달되는 것을 줄여주는 유지장치의 고안이 필요하다.

본 증례보고는 임플란트 실패를 경험한 상악골 절제술 환자에게 잔존 임플란트를 이용한 가철성 국소의치(implant assisted removable partial denture, IARPD) 형태의 구개폐쇄장치를 제작하여 기능과 심미성 회복을 이룬 보철수복을 보고하고자 한다.

(구강회복응용과학지 2016;32(4):322-9)

주요어: 상악골 절제술; 구개폐쇄장치; 임플란트를 이용한 가철성 국소의치 